\title{
Reduced negative surface charge on arterial endothelium of diabetic rats
}

\author{
I. Raz ${ }^{1}$, Y.Havivi ${ }^{2}$ and R. Yarom ${ }^{2}$ \\ Departments of ${ }^{1}$ Medicine B and ${ }^{2}$ Pathology, Hadassah University Hospital, Jerusalem, Israel
}

Summary. Cationized ferritin binding was used to measure negative surface charge on endothelium of large arteries in streptozotocin-induced diabetic rats and normal control rats. The negative charge was significantly lower in the diabetic animals $(p<0.01)$. This change, possibly related to glycosyla- tion, may lead to altered vascular permeability and may be of importance in the vascular pathology of diabetes.

Key words: Cationized ferritin, negative charge, endothelium, diabetic rats.
The endothelial cell surface bears a negative surface charge at physiological $\mathrm{pH}$ due to heparin-like sulfated mucopolysaccharides as well as neuraminidase sensitive (sialic acids) and resistant anionic groups [1-3]. It has been suggested that this negative charge exerts an electrostatic repulsion which contributes to the non-reactivity of normal endothelium with circulating blood constituent blood cells and platelets [4]. Changes in endothelial cell surface charge may be important in disease processes such as atherosclerosis and thrombosis, which are especially prevalent in diabetes [5].

It is known that in diabetic mice the concentration of heparan sulfate proteoglycan in the basement membrane is $20 \%$ of that in normal mice [6]. Glycosoaminoglycans of the renal glomerular basement membrane contain anionic sites that regulate the charge-selective nature of the glomerular filtration barrier [7,8]. These glycosaminoglycans are reduced in glomeruli of diabetic rats which may account for the defective function in their glomerular filtration barrier [9]. The erythrocyte surface concentration of sialic residues and, therefore, their surface negative charge is also significantly lower in diabetic patients than in healthy subjects $[10,11]$.

There seem to be no reports on the endothelial surface negative charge of large vessels in diabetes, the usual site of atheroma; therefore, we performed the study presented here.

\section{Materials and methods}

Twenty randomly bred male sabra rats from the Hebrew University breeding colony, weighing $175-225 \mathrm{~g}$ were housed in groups of two at $24^{\circ} \mathrm{C}$ and 12-h light dark cycles. All the rats were fed with Amrod \# 935 (Ambar Food Mills, Israel). This diet contained a minimum of $17.3 \%$ protein $4 \%$ fat, $47.9 \%$ carbohydrate and $8.3 \%$ fibre. All the rats had free access to water and food.

Ten animals were rendered diabetic by injection of $50 \mathrm{mg} / \mathrm{kg}$ of streptozotocin (Sigma Chemical Co., St. Louis, Mo, USA), buffered

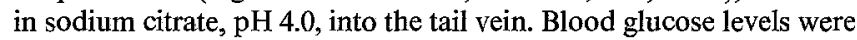
measured $48 \mathrm{~h}$ after the injection using the glucose oxidase method [12]. All animals with blood glucose levels under $14 \mathrm{mmol} / 1(n=3)$ were excluded from the experiment. The control animals received sodium citrate buffer only.

Body weight, blood glucose, and glycosylated haemoglobin $\left(\mathrm{HbA}_{1 \mathrm{c}}\right)$ of the rats in both groups were measured after 5, 60 and 120 days. Plasma glucose was measured by glucose oxidase/peroxidase as described [12]. Glycosylated haemoglobin $\left(\mathrm{HbA}_{1 \mathrm{c}}\right)$ was determined by the thiobarbituric acid colorimetric assay [13] (Normal range 5.5-8\%).

Negatively charged surface sites were visualized by electron microscopy using positively charged cationized ferritin [3] which, when applied following aldehyde fixation, electrostatically "stains" surface anionic groups in their native distribution [14].

One-hundred twenty days after the induction of diabetes 5 diabetic rats and 5 control healthy rats were anaesthetised with ether. They were then perfused through the left ventricle with a mixture of equal parts of phosphate buffered saline (PBS) and Karnovsky fixative containing 1\% formaldehyde and 3\% glutaraldehyde in $0.1 \mathrm{~N}$ cocodylate buffer $\mathrm{pH}$ 7.4. The perfusion was continued for $20 \mathrm{~min}$ under pressure of $110 \mathrm{mmHg}$. Pieces of thoracic aorta, coronary and renal arteries were dissected and immersed for another hour in $2.5 \%$ glutaraldehyde in cocodylate buffer ( $\mathrm{pH} 7.4)$. The samples were washed 3 times, in PBS and incubated in a solution of 
cationized ferritin $0.5 \mathrm{mg} / \mathrm{ml}$ (Bio-Yeda, Rehovot, Israel) diluted with PBS. The solution was constantly agitated for $30 \mathrm{~min}$. The specimens were then washed 3 times, $10 \mathrm{~min}$ each in PBS and postfixed for $1 \mathrm{~h}$ at $4^{\circ} \mathrm{C}$ in $1 \%$ osmium tetroxide in $0.1 \mathrm{~mol} / 1$ cocodylate buffer. After dehydration in graded alcohols the material was embedded in Araldite. Three blocks from each specimen were sectioned at a thickness of $50 \mathrm{~nm}$. These were examined unstained with a Philips 300 electronmicroscope. Four random areas containing the ferritin labelled endothelial cells were photographed in each block at a magnification of $\times 12,000$. The negatives were enlarged in a microfilm projector to $\times 360,000$. A transparent grid with 500 squares (measuring $1 \mathrm{~cm}$ each) was superimposed on the screen and the number of ferritin particles in 16-20 squares was counted on each picture. In this way the mean $\pm S D$ per square was derived from about 200 squares in each case. Knowing the exact enlargement the number of bound particles per $\mu \mathrm{m}^{2}$ was calculated.

\section{Statistical analysis}

The results for each vessel from the rats in each group were averaged $( \pm S D)$ and compared for significance of the differences with the Student's t-test.

\section{Results}

Animals administrated streptozotocin lost up to $10 \%$ of their initial body weight during the five day period following the injection. Thereafter, the diabetic rats gained weight at a slower rate than the control rats.

The mean weight, blood glucose levels, and $\mathrm{HbA}_{1 \mathrm{c}}$ during 120 days of follow up in the 5 diabetic and 5 control rats used in the experiment are listed in Table 1. It can be seen that during this period the streptozotocin-injected rats had severe uncontrolled diabetes.

Transmission electron microscopy of sections stained with uranyl and lead did not reveal any morphological changes in the diabetic arteries in the time periods studied.

In the unstained sections the cationized ferritin particles adhering to the luminal surface of the endothelial cells were well visible and abundant in slightly tangential sections (Figs. $1 \mathrm{a}$ and b). The difference in
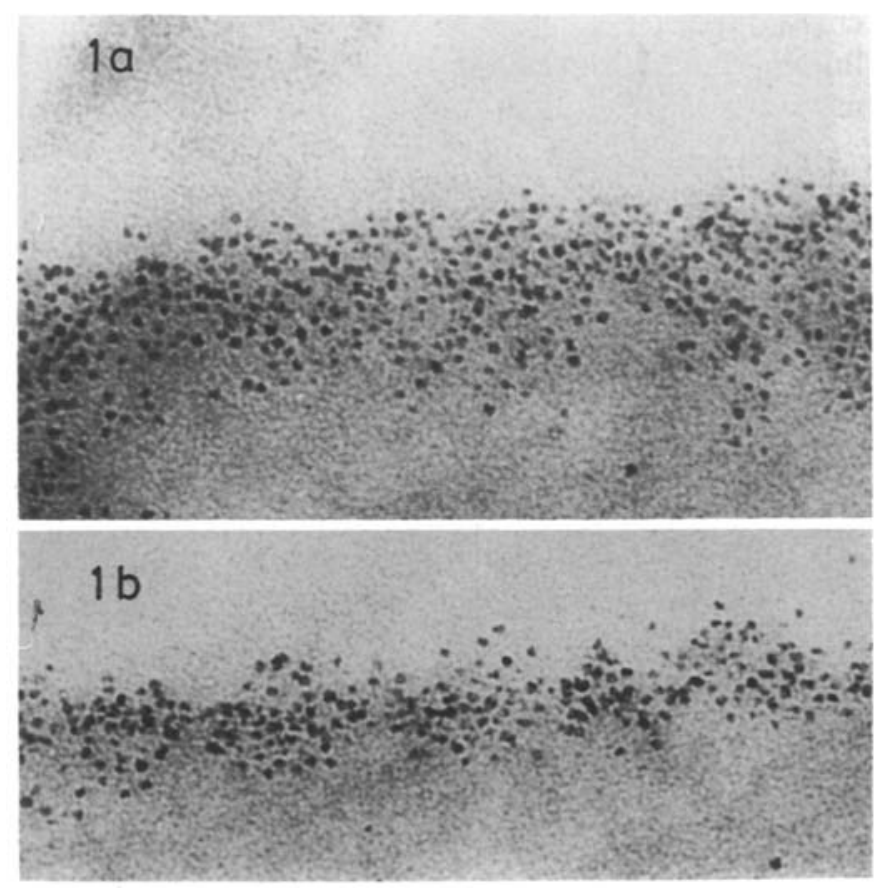

Fig. 1a and b. Micrograph of unstained, slightly tangential sections of rat aortas (control, 1a; diabetic, 1b) pretreated (after fixation) with $0.5 \mathrm{mg} / \mathrm{ml}$ of cationized ferritin $(\times 230,000)$. The number of particles is not obviously different but after counting the diabetic rats proved to have a significantly lower particle density

particle density was not visibly remarkable but proved to be significant in all the arteries checked $(p<0.01)$ on morphometric analysis (Table 2).

\section{Discussion}

It is known that the endothelial cell surface bears a negative charge at physiologic $\mathrm{pH}$ [3]. This negative surface charge might contribute by electrostatic repulsion to the non-reactivity of the normal endothelial lining with circulating blood cells and platelets [4]. It was found that the uptake of low density lipoprotein (LDL) and fibrinogen from circulating blood was in-
Table 1. Weight and glucose homeostasis in diabetic and age matched control rats

\begin{tabular}{|c|c|c|c|c|}
\hline & & \multicolumn{3}{|c|}{ Day after streptozotocin injection } \\
\hline & & 5 & 60 & 120 \\
\hline $\begin{array}{l}\text { Weight } \\
\text { (g) }\end{array}$ & $\begin{array}{l}\text { Diabetic rats } \\
\text { Control rats }\end{array}$ & $\begin{array}{ll}204 & \pm 4.5 \\
210 & \pm 5.1\end{array}$ & $\begin{array}{ll}233 & \pm 7.9^{\mathrm{a}} \\
289 & \pm 6.6\end{array}$ & $\begin{array}{l}282 \pm 8.1 \\
418 \pm 12.2\end{array}$ \\
\hline $\begin{array}{l}\text { Mean blood } \\
\text { glucose } \\
(\mathrm{mmol} / \mathrm{l})\end{array}$ & $\begin{array}{l}\text { Diabetic rats } \\
\text { Control rats }\end{array}$ & $\begin{array}{r}19.5 \pm 1.4 \\
4.8 \pm 0.2\end{array}$ & $\begin{array}{c}22.3 \pm 1.0^{\mathrm{a}} \\
5.0 \pm 0.2\end{array}$ & $\begin{array}{c}21.9 \pm 0.9^{a} \\
5.5 \pm 0.3\end{array}$ \\
\hline $\mathrm{HbA}_{1 \mathrm{c}}(\%)$ & $\begin{array}{l}\text { Diabetic rats } \\
\text { Control rats }\end{array}$ & $\begin{array}{l}4.8 \pm 0.3 \\
4.7 \pm 0.4\end{array}$ & & $\begin{array}{r}12.2 \pm 0.4 \\
4.9 \pm 0.4\end{array}$ \\
\hline
\end{tabular}

${ }^{a}$ The differences between diabetic and control rats are significant, at $p<0.001$ )
Table 2. Number of cationized ferritin particles per $\mu \mathrm{m}^{2}$ in various

\begin{tabular}{lcc}
\hline Arteries & $\begin{array}{l}\text { Diabetic rats } \\
(5)\end{array}$ & $\begin{array}{l}\text { Control rats } \\
(5)\end{array}$ \\
\hline Aorta & $7690 \pm 1310$ & $11300 \pm 1120$ \\
& $(5060-9300)$ & $(10000-14300)$ \\
Coronary & $8500 \pm 1400$ & $11720 \pm 1600$ \\
artery & $(5710-9900)$ & $(9980-1480)$ \\
Renal & $9020 \pm 2100$ & $13510 \pm 1520$ \\
artery & $(6500-11400)$ & $11900-15100)$ \\
\hline
\end{tabular}

Results are mean \pm SD from vessels 120 days after streptozotocin or saline injection (the ranges are in brackets). The differences between diabetic and control rats are significant at $p<0.01$ ). 
creased in arteries which in spite of an intact endothelium had diminished sialic acid moieties on their luminal surfaces $[15,16]$.

The diabetic state has been shown to cause a decrease in negatively charged molecules such as heparan sulfate and sialic-acid moieties on some cell surfaces. Heparan sulfate is found to be diminished in the glomerular basement membrane [9] and sialyl residues are significantly reduced on the erythrocyte surface of diabetic patients $[10,11]$. In diabetic rats and rabbits [17-20] abnormalities in glucosaminoglycan concentration of aorta were also found. However, their distribution in the arterial system of diabetic dogs was uneven and surprisingly increased in some arteries [18].

In the present study we could demonstrate a decreased negative charge in large arteries such as aorta, renal and coronary arteries of diabetic rats.

Diabetes is known to be associated with enhancement and acceleration of atherosclerosis [21]. Since atherosclerosis is associated with the accumulation of LDL-cholesterol and fibrinogen in arterial walls [22], an increased uptake of these substances might occur with reduced negative charge of the endothelium. Therefore, it is likely that the decreased negative charge of the endothelium plays a role in the pathogenesis of diabetic atherosclerosis.

Acknowledgment. This study was made possible due to the generous help of Mrs. Francis Mandel of Toronto, Canada.

\section{References}

1. Bionassisi B, Poot M (1975) Enzymatic degradation of heparinrelated mucopolysaccharides from the surface of endothelial cell cultures. Biochim Biophys Acta 385: 1-10

2. Skutelsky E, Rudich Z, Danon D (1975) Surface charge properties of the luminal front of blood vessel walls: an electron microscsopical analysis. Thrombosis Res 7: 623-631

3. Danon D, Goldstein L, Marikovsky Y, Skutelsky E (1972) Use of cationized ferritin as a label of negatiave charges on cell surfaces. J Ultrastruct Res 38: 500-510

4. Sawyer PN, Srinivasan S (1972) The role of electrochemical surface properties in thrombosis at vascular interface-cumulative experience of studies in animals and man. Bull NY Acad Med 48: 235-257

5. Berenson GS, Radhakrishnamurthy B, Srinivasan SR, Vijayagopal P, Dalferes ER, Sharma L (1984) Recent advances in molecular pathology: carbohydrate-protein macromolecules and arterial wall integrity. A role in atherogenesis. Exp Mol Pathol 41: 267-287

6. Rohrbach DH, Wagner CW, Star VL, Martin GR, Brown KS, Yoon JW (1983) Reduced synthesis of basement membrane heparan sulfate proteoglycan in streptozotocin-induced diabaetic mice. J Biol Chem 258: 11672-11677

7. Kanwar YS, Farquhar MG (1979) Anionic sites in glomerular basement membrane: in vivo and in vitro localization to the laminae rarae by cationic probes. J Cell Biol 81: 137-153

8. Brenner BM, Hostetter TH, Humes HD (1978) Molecular basis of proteinuria of glomerular origin. N Engl J Med 298: 826-833

9. Wu VY, Wilson B, Cohen MP (1987) Disturbances in glomerular basement membrane glycosaminoglycans in experimental diabetes. Diabetes 36: 679-683

10. Suganuma T, Ohta T, Tsuyama S, Kamada T, Otsuji S, Murata F (1985) Qualitative and quantitative analysis of erythrocyte surface membrane sialyl residues using affinity cytochemistry with special teference to diabetic patients. Virchows Arch [B] 49: 1-11

11. Baba Y, Kai M, Setoyama S, Otsuji S (1978) The lower levels of erythrocyte surface electric charge in diabetes mellitus. Clin Chim Acta 84: 247-249

12. Raabo E, Terkildsen TC (1960) On the enzymatic determination of blood glucose. Scand J Clin Lab Invest 12: 402-407

13. Parker KM, England JO, Da Costa J, Hess RL, Goldstein DE (1981) Improved colorimetric assay for glycosylated hemoglobin. Clin Chem 27: 669-672

14. Pelikan P, Gimbrone MA, Cotran RS (1979) Distribution and movement of anionic cell surface sites in cultured human vascular endothelial cells. Atherosclerosis 32: 69-80

15. Gorog P, Born GVR (1982) Increased uptake of circulating lowdensity lipoproteins and fibrinogen by arterial walls after removal of sialic acids from their endothelial surface. Br J Exp Path 63: 447-451

16. Sarphie TG (1986) A cytochemical study of the surface properties of aortic and mitral valve endothelium from hyperchoelsterolemic rabbits. Exp Mol Pathol 44: 281-296

17. Brosnan ME, Sirek OV, Sirek A, Przybylska K (1973) Effect of pancreatectomy with and without hypophysectomy and of insulin treatment on the composition of canine aorta. Diabetes 22: $397-402$

18. Sirek OV, Sirek A, Cukerman E (1980) Arterial glycosaminoglycans in diabetic dog. Blood Vessels 17: 271-275

19. Cohen MP, Foglia VG (1970) Aoartic mucopolysaccharides in experimental diabetes. Diabetes 19:639-643

20. Ichida T, Kalant N (1968) Aortic glycosaminoglycans in atheroma and aloxan diabetes. Can J Biochem 46: 249-260

21. Banga JD, Sixma JJ (1986) Diabetes mellitus vascular disease and thrombosis. Clin Haematol 15: 465-592

22. Smith EG, Staples EM (1980) Distribution of plasma proteins across the human aortic wall. Barrier functions of endothelium and internal elastic lamina. Atherosclerosis 37: 579-590

Received: 11 February 1988

and in revised form: 16 May 1988

Prof. R. Yarom

Department of Pathology

Hadassah University Hospital

POB 12000

Jerusalem, 91120

Israel 